\title{
BEAUTIFUl THINGS AND MEINONG'S \\ OBJECT THEORY: \\ AESTHETIC PROPERTIES IN FRONT OF Us?
}

\section{Bruno Langlet}

(Penultimate draft - article published in Meinong Studies IV, V. Raspa (ed), The Aesthetics of the Graz School, Ontos Verlag, 2009.)

\section{Summary}

There is no complete theory of aesthetics in Meinong's works, but more or less sparse remarks about the way Object Theory is to deal with so-called aesthetic properties. The apprehension and status of such properties mark anew meinongian problems about properties as abstracted from things, and as objects. Their status in object theory is to be clarified as they involve notions of internal and external dependence. Such notions are operative in Meinong's work since the psychological period, and they are linked with concepts of objects, higher order objects and objectives, which appear here to be also problematic regarding aesthetical objects. The late meinongian feeling-based theory aims to ground directedness toward aesthetic properties, and to preserve their occurrence in complex entities and their particular realistic status.

\section{Introduction: Meinong's views, troubling features?}

From a contemporary point of view and at first sight, Meinong's perspective on aesthetical problems can look like a confusing attempt to articulate various features that we would see as impossible to conceal. Features like strong realism, feeling-expressivism, response-dependent access to 
properties seem to refer to views we are used to distinguishing clearly. In Meinong's view, aesthetical properties appear to involve a very realistic commitment although his view is feeling-based. Meinong argues that emotions or aesthetic feelings present aesthetic properties as their proper objects, and as a consequence of such a presentation, these properties should really be conceived as being there and belonging to real things and artistic productions. Aesthetic feelings are here linked with aesthetic properties and give access to them, but they do not produce them. This feeling-based theory, which seems to articulate a strong realism with a response-dependent theory, is also a cognitive theory understanding emotions as a kind of quasi-knowledge. At the same time, beauty is not properly perceived, but is a special kind of object graspable only via emotions. The feeling does not contain the aesthetic and real property as represented, but shows some directedness toward it, and involves, according to Meinong, the realism of properties aimed at.

We may find that these features could hardly be sustained together. For example, in an expressivistic theory, feelings are the conditions for attributing aesthetic properties to things. But this is usually conceived in such a way that a cognitive and realistic account seems difficult to endorse. On one hand, so-called properties seem to have to be identified with projections of feelings on objects. They can't be taken as a proof of the acknowledgement of the real being of these properties. On the other hand, if aesthetic properties are not some projections of feelings, how are we to think them as being really there, and only accessible through emotions? Emotions should reveal their presence, but what kind of process is involved in such a cognitive relation, and in this intercourse, how emotions can happen to be a path for knowledge about aesthetic properties?

In another manner, how can we think aesthetic properties are really here and make our feelings happen? Aren't we committed to the claim that the feelings must represent the properties in some way? But it seems difficult to understand how a feeling can represent a property as it is in a thing, assuming that it could be in a thing. If feelings are caused by properties but are not representing them, then it seems difficult to talk about knowledge. It could be knowledge that something aesthetical is here, without exactly knowing what is there. But how do we know that what is 
there is really aesthetical in kind? How can we distinguish such a view from a doctrine arguing that ordinary features cause the feeling of beauty, feeling in virtue of which we attribute beauty to the thing and its ordinary features, but where aesthetical properties are nothing else than hypostatizations of these feelings? We come back to an anti-realistic responsedependent theory.

Thus we might have to assume that the theory of objects operates a combination of some incompatible aspects of these views, and that, as a consequence, this theory should retrospectively be seen as a kind of irrationalized syncretism. But it is of course wiser to doubt that and to assume that the theory of objects does offer something else regarding aesthetical problems. Because Meinong seems to have elaborated his view with knowledge of ideas parented to those exposed above. As a matter of facts, Meinong refuses that aesthetical properties are feelings hypostasized and wrongly attributed to objects. He refuses also that we are intellectually grasping beauty. But he maintains a realistic position and he argues that emotions are the way to apprehend truly aesthetical properties, and that, thanks to this process, we happen to be quasi-justified in attributing such properties to a thing. We have to understand what this means inside the object theory.

\section{Marking the difficulty.}

What is here at stake is not meaningful only in the scope of the Theory of objects. In one hand, it shows a difficulty belonging to every conception of aesthetics. It is classical to recognize that aesthetic properties are not usual properties, assuming that they are properties at all. But they seem to exist in one way or another, and moreover, as we experience beauty or ugliness, we seem to be compelled to see them in some precise things and not in others.

How does Meinong deal with classical problems of aesthetics, and what is the theory of objects accounting for in such matters ${ }^{1}$ ? The ques-

Fictional objects are not under particular focus here. I take aesthetic properties in a basic sense: what is aimed at when we talk of a beautiful chord or an ele- 
tion aims to aesthetical problems as they are treated through the theory of objects. For example, in his Selbstdarstellung, Meinong says that like red, beauty is an attribute of things. We can't suppose that old illusions about the objectivity of beauty are trapping this view. Meinong's goal here is to show that talks about beauty are never talks about the very causes that make us attribute beauty to objects. Indeed we do not talk about the cause of attribution of red to a rose when we are talking of the color of the flower, even if we know that causes are involved. And surely Meinong does not mean - in his mature work - that beauty is here as the red is, just because of that insight about our attitude about causes. He wants to explain our way of dealing with aesthetic properties, and this way is a realistic one. In order to understand this realistic commitment, we must question the true meaning received by this assertion in the theory of objects.

Assuming that this can take us to the heart of aesthetical problems, may be the form they receive in the theory of objects can furnish advantages. We could notice aspects of the difficulties we weren't aware of. We could find an interesting solution or frame for a future solution, assuming that the problem shows all its facets in such a view. The theory of object is neither a psychological theory nor an ontological one (in the classical sense). It is a theory exemplifying these two features. It is a theory treating our ontological and psychological involvements about the way we interact with different kinds of things. It is inseparable from a theory of intentionality, and may be we could see it like metaphysics of intentionality. The status of things, as they are under focus and as they behave in a particular way according to this, is what is at stake about the use of "object" (Gegenstand).

Among objects, Meinong distinguishes between objectum (Objeckt) and objective (Objektiv). Objecta are entities defined by their properties and by the way we apprehend them, namely by simple presentation. A property can be an object, like the red, as separated from its bearer, and as an idea's intentional correlate. An object can also exhibit various properties, like the oval triangle does. The oval triangle cannot exist because it

gant style, for example. For an account of fictional objects in the meinongian way, see Raspa (2006), and Barbero (2006). 
is constituted by properties that we can't attribute at the same time to an existing or subsisting object. But it is nevertheless an object since we have the intelligence of its properties, and as we can say that it has such properties that he couldn't exist as exemplifying both of them at the same time. As we see, an object is not a thing, and according to its modes of being, an object stands to its properties in different ways.

Objectives (Objektive) are usually conceived as propositional objects, or states of affairs-like. Objectives can be positive (like when we considerer the fact that the book has a rectangular form) or negative (like when one judges that it is not allowed to smoke in here). If the psychological act is a judgment, then there is conviction. If the act is an assumption, then we do not have this conviction. Objectives are the ontological correlate of such acts, and describe the relationship between things we are dealing with as objects when we are judging or assuming relations between their properties. That makes a complex object, that is, an objective where relations appear clearly. It is not clear if such objects are propositions or states of affairs. May be these categorizations don't exactly fit for them. As we can see, objecta and objectives involve a specific directedness, and as presentations give access to objecta, judgments and assumptions are modulations of this directedness regarding propositional objects. What about emotions? What kind of directedness and correlates do they involve when they point to aesthetic properties?

The true understanding of Meinong's positions supposes nuances and inquiry on this. Indeed, emotions can be seen as furnishing a mode of directedness toward aesthetic properties. According to Meinong, and thanks to aesthetic feelings, we are able to grasp these properties by a kind of intuition-like process. The directedness constituted from such a basis contains an involvement to see beauty as a real beauty of a something. The quest for explanation of this involvement is our subject.

This supposes to understand the characteristic directedness here taking place. In such a view, emotions are showing a kind of intentionality or directedness, but they lack the transparency of our ordinary representations, exemplified for instance through the clear apprehension of an object via an idea. Concerning emotions we seem to have to talk of directedness without clear representation. But this does not necessarily mean 
without a kind of knowledge. We would be able to see this relation as a kind of knowledge relation, if we can understand it as a presentation involving a justified believing in the presence of aesthetical features. So, if we can understand what governs such directedness and the implications of its occurrence, we shall be able to understand a part of the realistic and (quasi) cognitivistic account of the Meinong's position.

Another part of the difficulty is to understand how to justify the attribution of properties on the basis of emotions, namely through states of mind supposed to testify to the aesthetical nature of these properties and their belonging to something. In this perspective, we must show that occurrences of emotions testify to aesthetical properties as their object. The solution proposed by Meinong goes this way. Apparently, such a solution rests on the subtleties of his theory of objects. But in Meinong's view and through the way he understands the role of emotions, their cognitive dispositions and the realism of aesthetical properties, we have an exemplification of the fact that objects behave in such a manner that they reveal strong and objective properties, constraining us to represent them in one way and not in another one. This should be seen as a criterion of reality. This may happen in the aesthetical domain, with some reserves well stated by Meinong. So if his view can explain that aesthetic emotions must arise in a precise context of intercourse with objects, then we have our link between emotions and aesthetical objects.

This implies taking clearly into account the peculiar status of aesthetic properties, their nature being nevertheless controversial in Object Theory. For example, Witasek and Meinong disagree about the objects (in a large sense) of aesthetic feelings. Our aim is to examine the Meinong's position, where we find a refusal of objecta as adequate targets of our aesthetic emotions, and at the same time, the acknowledgment that objectives-like entities are fitting. This debate is a large one and cannot fully be examined here. But there are some key notions to find out some useful and critical entrances in the Meinong's view. One of them is the status of abstracted properties, conceived alongside with the operative concepts of internal and external dependence. Such concepts happen to be under Meinong's attention since his early writings, and the problem of the status of aesthetical properties involves them anew in the late writings. 


\section{Internal and external dependence. From abstracted contents to aesthetic higher order objects.}

The status of an aesthetic property is immediately problematic in the theory of object as this property is inseparable from other properties conceived as its basis. This relationship of inseparability appears to be a dependence feature, and we will talk here of a dependence relation. Such a relation occurs in a way that has motivated a supervenience theory of beauty, outside of meinongian views. Base properties make up an aesthetic property that is strictly linked to them, in a mysterious way, and this last property can neither be reduced to its basic properties nor thought about without them. In its own terms, the theory of objects is facing the same kind of problem. We might think that this theory is very well prepared to deal with this, simply because this is the theory where higher order objects were conceived. But things are not so easy.

In the object theory apparatus, some features are under focus. One of them relates to considerations where aesthetic properties are taken as objects, in a large sense. Object theory is dedicated to the understanding of the nature of things as they are given to us, in a complicated way exemplifying both phenomenological and dialectical sides of our thinking. These sides are strongly interconnected. Meinong's position involves a relation between thinking and acting subjects and their objects. In a concrete world, to refer cognitively to a thing involves picking out something of this thing, in such a way that the something is presented and known to belong to the thing. Such an act implies the very notion of object: for as an abstracted property is targeted, the object becomes the ontological correlate of this intentional relation. The object theory can be seen as an exploration of the active ontological presuppositions necessary to explain such acts and what is given through them. For our intercourse with things around is always conducted on abstractive ways, since we cannot apprehend our surroundings in all their respects. As far as this concerns considerations about the repeatable status of properties, one can see here a 
motive for the occurrence of incomplete objects in the object theory equipment.

As a matter of facts, the very notion of abstraction is present in Meinong's works since his psychological researches and his writings on Hume. For example, Meinong was interested on the status of mind's acts correlates - objects, or during the psychological period, contents, - in order (among other interests) to find out to what extent we have to suppose real complexity in a given object to explain that we can mentally separate properties from $i^{2}$. One can see that aesthetic properties are troubling from this point of view. Are they abstracted? We do consider them as distinct from other properties. This is necessary in order to identify them as aesthetical. But as we can see, this distinction is problematic: what is really under focus here? Could they be abstracted from their basis without vanishing? The problem is that they are showing strange features.

In his psychological writings about the theory of mental analysis of given contents ${ }^{3}$, Meinong identifies two kind of properties understood as very different in two respects. The difference is first determined by the presuppositions regarding our ability to apprehend them in an abstractive way. Second, these presuppositions relate directly to dependence upon other contents. Statements concerning internal and external dependencies do appear here. An externally dependent content makes sense insofar as its cognitive content is well determined and need no other content, although in reality, to be exemplified, the represented property supposes other properties. The abstractive thought about this content can be cognitively complete without these other properties. For example, red exhibit an external dependence upon extension. Of course there is no color without extension. But nothing about extension is necessary to the content of the idea of a color. On the contrary, an internally dependent content cannot be apprehended without other contents. We need to have them in order to have the content. This is a limitation for abstractive procedures. For example, we cannot have a melody without representations of the tones, nor, according to Meinong's example, can we have a shape without representation of spatial locations. We have there founded contents, the 
ancestors of founded objects and of higher order objects. This leads to a qualification of the foundation of internal dependence: such foundation appears always to be constituted by a plurality ${ }^{4}$.

This distinction between a kind of internal dependence and an external one goes through Meinong's work, even after the introduction of the Object theory. In the text on higher order objects, Meinong states again this distinction, and focuses his attention on objects that are exemplifying the internal dependence ${ }^{5}$. The characteristic of higher order objects is that the superius cannot be isolated from its inferiora without vanishing. Otherwise, it could only be represented in a very abstract sense and is embedding the meaning of a difference without precise different objects.

Cf. Meinong (1894).

"Auch Farbe ist, weil tatsächlich oder vielleicht selbst notwendig an andere Inhalte, wie Ort, Ausdehnung usf., geknüpft, nicht kurzweg selbständig; aber man kann diese Selbständigkeit ganz wohl eine äußerliche nennen im Vergleich mit jener sozusagen innerlichen Unfertigkeit, welche dem Relationsgedanken ohne die Relationsglieder anhaftet, indes Rot oder Süß bei aller Gebundenheit an Begleittatsachen ein sich gleichsam Abgeschlossenes darstellt. In diesem Sinne rede ich von inner Selbständigkeit der absoluten, innerer Unselbständigkeit der Relationsinhalte und stelle vor allem Frage, ob die fundierten Inhalte zu den innerlich selbständigen oder unselbständigen gehören.

Die Antwort stellt sich von selbst ein: was sollte man auch unter einer Gestalt ohne Ortsbestimmungen, was unter einer Melodie ohne Töne denken? Wir können kurzweg sagen: Alle fundierte Inhalte sind innerlich unselbständig. Es empfiehlt sich aber, wenn vielleicht auch nur, um Missverständnissen vorzubeugen, hinzuzufügen: Dasjenige, dem gegenüber sie unselbständig sind, ist jederzeit, eine Mehrheit; Eine Ortsbestimmung macht niemals eine Gestalt, Ein Ton niemals eine Melodie aus." Meinong (1894), pp. 322-323.

"Es gibt bekanntlich Gegenstände, denen man eine in ihrer Natur gelegene innere Unselbständigkeit nachsagen kann. Ich meine nicht jene Unselbständigkeit im Auftreten, vermöge welcher etwa Farbe sich nicht ohne Ausdehnung vorstellen lässt. Auch diese Unselbständigkeit mag in der Natur von Farbe und Ausdehnung begründet sein: aber man kann sie immer noch äußerlich nennen gegenüber jener, ich möchte sagen Unfertigkeit, welche z. B. dem Gegenstand „Verschiedenheit" anhaftet, wenn man ihn von dem, was verschieden ist, zu isolieren versucht. Ich kann den Verschiedenheitsgedanken einfach nicht ausdenken ohne Bezugnahme auf Objekte, an die er sich gleichsam heftet, indes es mindestens einen ganz guten Sinn hätte, zu meinen, im Gedanken an Blau oder Gelb liege noch gar nichts von Räumlichkeit, obwohl es unmöglich sei, Farbe zu denken, ohne Ausdehnung mitzudenken." Meinong (1899), p. 386. 
Of course, we can talk of difference or similarity without thinking about inferiora. But we cannot think to a precise difference between things without representing these latter.

These dependence features appear to be correlated with difficulties relative to aesthetic properties: cause thinking of beauty, we will find that such a property behaves according to internal dependence. But our way of attributing beauty seems to show that a monadic base is assumed, and not a pluralistic one ${ }^{6}$. So troubles begin here with this characterization of aesthetic objects. Could they be simple objecta? Here stands the motive of the disagreement between Meinong and Witasek. Before focusing on some reasons expressed from both sides, how to understand the apprehension of beauty as objectum? There are various senses to put it.

If aesthetical properties could be apprehended as objecta, they should have been picked out without the properties they supervene on, as one would say. We should be able to access this beauty without needing ordinary things upon which beauty is dependent. We can talk about beauty, but can we represent beauty as such without a determinate something being beautiful? This is impossible. Otherwise, we would be able to think of beauty as an object, and having a presentation of an absolutely undetermined something beautiful. We can apprehend a something blue, but we can't apprehend a something beautiful, ugly, sublime, or elegant in this full abstractive way. So according to our experience of beauty, such a property behaves apparently like something standing in an internal dependence relation (in Meinong's sense) with a basis. In order to access some beauty, this basis must also be experienced. Red can be an object, but beautiful cannot be.

As beauty is linked with internal dependence, we may think of it as a higher order object. From this point of view, beauty is a superius. But we attribute beauty to a single thing. That's one of the reasons explaining the Witasek's attempts to conceive the objects of our aesthetic feelings as $o b$ jecta, and not as objectives. As we talk about the beauty of a melody, we attribute beauty to the melody itself, not to the complex tones founding the melody. From the point of view of the object theory apparatus, we

6

Cf. Meinong (1917), pp. 104 f. 
have a higher order object manifesting rightly an internal dependence, but which appears to be founded on a monadic base - the melody as a whole.

If we add to this the fact that aesthetics objects cannot be apprehended through a productive process, then troubles seem to go further in the object theory. Because this process is a necessary one in order to apprehend important objects. Real or ideal relations or complexions cannot become graspable objects without such process. If it were so, we would be hearing an aggregation of tones and no melody, we would be considering two or more things, but no difference or similarity between them, and as a consequence, no connected complex would be available to our thinking. So this process seems to be essential to the apprehension of higher order objects.

Maybe we can think that we are able to apprehend aesthetic objects without this process, and as a matter of facts, this is the case in Meinong's view. Emotions do the job. But something important must be noticed here. Indeed, the relationship between internal dependence, plurality, and productive process plays another role in the apprehension of higher order objects. As a matter of facts, such elements are conditions for the directedness toward the object. Relations or objects of higher order are built on a complex of inferiora. For example, a melody is such an object and is built on series of notes. Could we be directed toward the melody without supposing the tones and without the production of the melody thanks to the plurality of tones? Of course not. They are conditions for the directedness toward the melody.

According to Meinong ${ }^{7}$, without productive process, and inferiora or psychological presuppositional contents, we cannot apprehend a precise relation and cannot be directed toward it, because such directedness requires an activity. Then we loose directedness toward higher order objects. This could seem obvious. But more importantly, this is a technical

"Eher dürfte ihr die Relation der Verschiedenheitsvorstellung zu den in Verschiedenheitsrelation stehenden Gegenständen an die Seite gesetzt werden, ohne die (unbeschadet weitgehender Variabilität derselben) die Verschiedenheit nicht (außer etwa irgendwie abstraktiv) erfaßt werden könnte. Aber von einem Gerichtetsein kann man auch hier immer noch nicht reden, [...]". Meinong (1917), p. 82. 
justification of the important notion of directedness, which is a key one in the object theory. Picking out, thanks to this process and its material, the similarity between two members of a family, we are presented with this particular similarity, which stands in front of us by virtue of the conditioned directedness involved in the process. The absence of productive process in emotional access to aesthetic objects highlights the problem about the grounding of feelings directedness. What is at stake here is also the problem of the directedness to a precise beauty - and beauty is always a precise and particular occurrence. Under this respect, the relationship between inferiora and the productive process is again a matter of importance. Concerning higher order objects, individuation seems to occur thanks to inferiora, which make the individuality of the Superius. For example, talking about the melody, Meinong argues that inferiora are what make a melody this melody, and not another one ${ }^{8}$. The relationship between inferiora and productive process happen to be conditions for the presentation of the melody as this melody, and to be directed toward it. One can see that if we do not have the process in the case of beauty, we could have difficulty to apprehend particular beauties - which is of course embarrassing. The superius is a particular. Sometimes a superius, according to its functional characteristics, can be found related to various groups of inferiora. This is the case for the object difference, for example. But as produced on the basis of precise inferiora, we apprehend this difference, the particular one standing between objects understood as different thanks to this process ${ }^{9}$. So the productive process is grounding the apprehension of particular higher order objects.

Reversely, the possibility of attributing such beauty or ugliness to things is also at stake. Both productive process and inferiora enable us to direct ourselves to the higher object strictly linked to these very inferiora. If we cannot apprehend the superius, we can't know that the superius is

8 "Sind die vorgegebenen Gegenstände Töne, so können sie nun aber auch noch als musikalisches Motiv, also sozusagen als einfachste Melodie ,aufgefaßt“" werden und auch diesmal fehlt die Notwendigkeit nicht, der gemäß diese Töne gerade diese Melodie ausmachen und keine andere.” Meinong (1899), p. 400.

9 "[...] natürlich nicht der Verschiedenheit schlechthin, sondern speziell der Verschiedenheit zwischen A und B." Meinong (1899), p. 398. 
the superius of these inferiora. If we access to a superius without this productive process, how are we to link it to its inferiora? How can we understand that emotions direct us to aesthetic properties and enable us to see them as belonging to a precise basic thing? This is a difficulty we have to state. From an ordinary higher order object, it is obvious to see that the superius is linked to particular inferiora. Because facing an object like difference, we cannot but link it to its inferiora. And obviously, by doing so we involve the knowledge that this relational property of difference qualifies objects or properties, from which such a difference has been emerging as an individuated object. So, the producing process can function as a basis in order to link properties to their owners, as higher order objects are linked to their inferiora. This link-feature is decisive in aesthetic matters, because for now, just inferiora appear to be the grounding for the directedness of emotions. Next to the problem of establishing the nature of aesthetical directedness, we find the correlated problem of the basis involved with the attribution of aesthetic properties to things.

So we need to find out how directedness is fulfilled in the case of aesthetical objects, in order to give access to their status (higher order objects) and to their individuality. Again, we need to know how the theory can deal with the apparently monadic base of such object. And what does emotional access involve about the real status of aesthetic properties? Aesthetic higher order objects can't be treated as objects whose inferiora are on a part with productive process to constitute directedness. But surely aesthetic higher order objects do have inferiora, as we have seen, because aesthetic properties cannot be there without them. The question takes us back to the connexion between these inferiora and the particular directedness induced via emotions. This is linked with the status of aesthetical objects, as they are objects of aesthetic feelings. Meinong doesn't think that they are objecta. They are more like objectives. Are objectives welcome to explain our directedness problem? Let's see. 


\section{Problems with Objectives.}

We find ourselves in front of beauty, without production process. Can we hypothesize that as we are facing beauty as a higher order object, we do apprehend an objective that makes us know that this thing is beautiful? How are we to understand this relationship with objectives in aesthetical matters? Thanks to an objective of so-being, the higher order object (beauty) may be given to us as a founded property, where we could have our special features exemplified and justified. We may access to beauty as separated and as linked to the object (for example, the melody) constituting its foundation. This could enable us to have an object with an internal dependence (in the Meinongian sense) upon a monadic base. Meinong claims that objectives are in some cases higher order objects with a monadic basis: for instance, objectives where we judge the being of something taken as a single thing ${ }^{10}$. Thus we could have higher order objects with a monadic base, assuming that they are apprehended through objectives.

If we consider beauty and its monadic base, haven't we two constituents for our objective, assuming that beauty is here above and over the ordinary thing? If this is right, an objective of so-being is par excellence the way to apprehend a property in its relation to a substrate. This looks like a solution to go one step beyond the problem of our aesthetic higher order objects. They are still higher order objects, and so objective does. But aesthetic higher order objects could be apprehended as objective-like entities, which means that they should involve a kind of judgment or assumption-like activities instead of the productive process. In such a view, for a beauty property to be presented is to be apprehended through an objective-like entity, where the property relation to a substrate is judged or assumed. We have our directedness, and a very precise relationship takes place. But this is theoretical. These features must be precisely accounted for, and the role of emotions must also be spelt out. Could objectives offer this kind of solution for our aesthetical problem?

10 Meinong (1917), pp. 106-108. 
One difficulty is that objectives imply relations between objects, that is, between some properties of the objects. Going back to what have been stated above about abstracted properties, one can see that objectives suppose such properties. As "propositional objects" or as states of affairs-like entities, they involve for example two properties standing in a particular relationship. Using some meinongian words, they involve incomplete objects. If I judge that some discs are on the table, I assert something through a relationship between spatial properties of such things. The color and size of the discs do not matter in such a judgment. So we have an objective corresponding to a special focusing. States of affairs as apprehended - i.e. objectives - are always made accessible through a directedness involving a selection between properties. This is the condition for state of affairs to be judged as obtaining, because a state of affairs obtains and is known to obtain only if precise relations between precise properties are judged to obtain. They must be under precise focus. So, an abstractive way of presenting these features is involved here, and this is what is required by any apprehension of objectives. An objective is always constituted by precise relationship between properties of objects, implicitly or not. This elaborated abstractive way of presentation of connexions between properties becomes immediately problematic as we turn to aesthetics. Could a thing and any aesthetic property constitute an aesthetic objective? For sure, this would be a solution to the aesthetic higher order object problem.

But as one can see, this cannot work. Objectives are constituted by available properties. An objective can contain funny relations between properties: we can assume that dragons have carbon fiber wings. Maybe this is not a factual objective. But the connected complex - here object of assumption - involves available properties. "Available" points here to objects capable of being presented. These objects are accessible through a basis of determined given properties. No matter if some of them are imaginative and other serious. Such objects can be seen as clear properties able to be linked and connected, because their characteristics enable us to do so. This does not mean that we have to obtain a factual objective. Yet we have an objective. In Über Annahmen, Meinong argues that objects may be apprehended thanks to objectives. But these objects must be al- 
ready given determinations, or clear properties. In a similar way, these determinations can be implicitly at stake when we are considering existing objects from the concrete world, thanks to objectives of so-being. Again, such objectives need to pick out already given and determined properties, selected among the sum of available properties as objects ${ }^{11}$.

The apprehension of a single object of the world, apparently given by a classical presentation, may involve at a deeper level objectives of sobeing. This is interesting for our problem, as it is the core of Meinong's opposition to Witasek. May be we are not directed toward aesthetic $o b$ jecta, but our attitude about aesthetic properties happen to be involving objectives of so-being, as the condition for the apprehension of such properties. The problem is that beauty is not exactly a pre-given determined property that could be available like being red, having some wings or being constituted by carbon fibers. And beauty cannot be an absolutely undetermined something just being beautiful. Beauty cannot be the only determination of a pure something abstractly considered. We need a determined something which could be said to be beautiful, in order to give some sense to an aesthetical qualification. This is necessary in order to get beauty as a constituent of the objective; otherwise beauty is just a word. But if we need a determination upon which beauty supervenes, we are begging the question. Cause this is exactly what objectives have been supposed account for! So we come back to the same problem, and the trouble remains about the status of beauty as a property.

Beauty seems to behave like a Sosein when apprehended thanks to a basis. But beauty is not available as a classical Sosein like other determi-

11 "Daß nicht nur Seins- sondern auch Soseinobjektive beim Ergreifen von Gegenständen eine Rolle spielen, kann demjenigen nicht auffallen, der der Tatsache eingedenk ist, wie doch eigentlich nicht das Sein, sondern das Sosein das Wesen der Gegenstände konstituiert. Alles Meinen kann ja wie erwähnt als eine Art Auswahl betrachtet werden, die aus der unendlichgradig unendlichen Fülle des Außerseienden auf Grund vorgegebener Bestimmungen getroffen wird. Diese Bestimmungen sind zuletzt Eigenschaften, also Sosein, und man könnte es eher bemerkenswert finden, daß ein Ergreifen vermöge bloßen Seins, d. h. ohne explizite Inanspruchnahme des Sosein möglich ist. Man wird eben vermuten müssen, dass schon in den Daten bloßen Vorstellens zusammen mit der auf sie gegründeten Seinsmeinung Soseinobjektive mindestens impliziert sind." Meinong (1910), p. 275. 
nations that are able to enter into an objective. Beauty being apprehended through objectives cannot be understood according to this classical way. Are objectives more a problem than a solution? Let's turn to a historical part of the Meinong-Witasek debate in order to find our way.

Witasek refuses that objectives do really matter for aesthetics. He finds that our way of attributing beauty to things is revealing that aesthetic feelings refer to objecta ${ }^{12}$. This is the core of Meinong's disagreement with him $^{13}$. The problem with objectives, according to Witasek, is that it is possible to transfer an objective involved in an aesthetic case to another case, and to loose the aesthetical features. For example, we cannot translate poems into prose without loosing the aesthetical features. According to Witasek, we still have the same objective in both cases, expressed and apprehended in different ways. So aesthetic features cannot be essentially linked with objectives. So we must assume that aesthetics feelings refer to objecta, like this poem or that other one. Witasek thinks that we have different classes of objects of aesthetic feelings, but all of them are objecta. So beauty is apprehended as an object, which seems adequate regarding the way we attribute beauty, namely to objecta like this color or shape, this melody, etc., and disregarding the role of the complexity grounding the very objectum.

Meinong's response to this point shows that Witasek is missing something about the links between objectives and these objecta to which beauty is attributed. In Über Annahmen, he argues indeed that such material must of course be taken into account, and that objectives are nevertheless involved ${ }^{14}$. Meinong thinks that instead of believing that aesthetic

12 For a presentation of Witasek's views on aesthetics, see Schumann (2001), and Smith (1996).

For a more extensive account of theoretical agreements and disagreements between Meinong and Witasek on aesthetics, see Raspa (2006).

"Wer gewissen Objektiven ästhetische Dignität zuspricht, meint damit sicher nicht das Objektiv nach Abzug seines Objektenmaterials, auch nicht das Objektiv in einer gewissen Beiläufigkeit, der gegenüber es auf Modifikationen hinsichtlich des Materials innerhalb weiterer Grenzen nicht ankommt. Es kann sehr leicht sein, dass die ästhetische Bedeutsamkeit sich von solchen Bestimmungen am Material abhängig erweist, eben denen, auf die sich auch Witasek beruft, - 
feelings are like presentations of Objecta, we must come to the understanding that implicit objectives are involved in our apprehension of aesthetic features. The very fact of our relation with objectives of so-being involves a more complicated relationship between objecta and aesthetic determinations ${ }^{15}$. Aesthetic feelings are supposed here to be directed toward implicit objectives of so-being. Meinong states here that aesthetic features are occurring in objectives and have property determination features. Of course, we still have our difficulty about the nature of properties aimed at in objectives.

In Über emotionale Präsentation, we have a change of focus. Meinong recognizes that objectives are not perfectly adequate, but he didn't turn back to objecta. He focuses on the involvements of our apprehension of beauty, and wants to put a light on the presuppositional objects of beauty experience, with their link with emotions, and with the objectivelike entity involved in such a complex way of apprehension. His position can be seen as a solution for the problem stated above. Presuppositional objects cannot give us access to a higher order object in a classical manner, since no productive process can occur. Objectives seemed to be able to offer another way in order to explain that beauty properties are given to us. Since apprehension of objectives supposes something is seen as thusand-thus, the presuppositional objects could be one part of an objective, and the apprehension of beauty property being the other part. But as we have seen, this is begging the question, since aesthetic properties are supposed to be given in an objective, and we are here saying that we already need them to constitute the objective. We have then to understand how

und dass gleichwohl das Objektiv der eigentliche ästhetische Gegenstand bleibt." Meinong (1910), p. 319.

"Es ist zunächst außer Frage, dass es ästhetische Gefühle genug gibt, die sich etwa auf eine Farbe, eine Gestalt oder dgl., also auf Objekte (genauer Eigenschaften) sonach fürs erste auf kein Objektiv richten. Wir haben aber oben in den Eigenschaftsbestimmungen Implikationen von Soseinsobjektiven erkannt. Könnte man daraufhin, wenn man solche Implikationen ausdrücklich einbezieht, nicht vielleicht von allen ästhetischen Gefühlen sagen, dass sie auf Soseinobjektive, wenn nicht explizite, so doch implizite, gerichtet sind?". Meinong (1910), p. 320 . 
aesthetic feelings can reveal aesthetic properties as higher order objects apprehended through an objective-like entity.

As Meinong remarks, we can see in our experience of beauty that features occur in such a way that we can see strong similarities with some features of objectives. Objectives show an opposition between the positive and the negative, as we noticed above, and imply conviction, supposing that they are judged objectives. Can emotions show features like this and make us think that they authorize access to beauty as a higher order object, by targeting an objective-like entity and no objectum? Contrary to "ordinary" access to higher order objects, aesthetic properties involve a duality similar with the objective's duality between positive and negative, namely the duality between beauty and ugliness. Given a basis apprehended as a presupposition, it happens to be that we are directed either to beauty or to ugliness. This cannot happen with ordinary access to higher order object: given two things, idea of difference is produced if we consider different features, and idea of similarity is produced if we consider similar features. Given some precise tones, we are directed to one melody and not to another one, as we have seen above. But given a melody, we can emotionally be directed toward beauty or toward ugliness, toward sublimity or awfulness. May be this is precisely enabled by the absence of productive process. Of course, we can refine and talk of more precise aesthetic features. But the duality seems to be inherent to such objects according to Meinong. So the occurrence of one of this side of aesthetical appreciation can make us think that aesthetical features, taken as higher order objects, show a behavior, as objects, which justify their belonging to the class of objective-like entities. Objecta do not behave this way. There is no such duality with the presentation of an objectum.

So our emotions are directed toward properties that are part of a complex with objective-like features. Moreover, as it is well known, aesthetic feelings are also value feelings. As they occur, they show a quality enabling the owner of the emotion to believe in the emotion's object. This is classical feature of emotions, as their occurrences involve a kind of believing in the being of what is presented through them ${ }^{16}$. Shall we say that

16 " $[. .$.$] wer an einen gewissen Voraussetzungsgegenstand ein Gefühl, also etwa$ zunächst ein Wertgefühl knüpft, sich darin durchaus im Rechte fühlt, so daß er 
this involves the being of the object in a strict sense? Actually, this is only involving the being of the property under focus, as possessed by something else, and the real possession of a property by something is different from the existence of this something. We can find beauty in imaginative objects. We do not attribute existence to what is imagined. But we do attribute beauty to such imagined objects. Beauty is believed to belong to the imagined object. This is similar with logical properties of things that do not exist. They have these logical properties. So the emotional occurrence and its directedness toward a property, by virtue of the believing involved in such feeling, presents itself as the analogon of the conviction that we can find in our intercourse with objectives. We are not here concerned with objective of being, but with something nearer to objectives of so-being. Emotion is directed to something being thus-and-thus, and emotion involves a believing in the reality of the so-being - but not necessarily a believing in the existence of the thing which is so and so. But the reality of the relation between the so-being and its substrate (may be this one is imaginative) is an involvement. As Meinong puts it, a beautiful imagined chord is, may be, less impressive than the real one, but it is still beautiful.

Two consequences in such a view: first, emotions imply a believing about the so-being of a something, and show a conviction-like feature parented with what defines an interplay with an objective. Second, emotion acts like a criterion of reality, simply because of its occurrence. So if we combine this feature with the so-being feature and with the believing involved in, we have a quasi-justified directedness toward the real presence of a beauty property of something determined. These complicated processes imply also the acknowledgment of an aesthetic value, and to be characterized, the peculiar objective-like we are dealing with is to receive the name of Dignitative.

These aspects fit with the internal dependence of aesthetical objects, because they occur by virtue of the being given of intellectual presuppositional objects. These objects are foundations and substrate for aesthetical features: the complex process described above involves a feature that is

ohne weiteres bereit ist, ein entgegengesetztes Verhalten zu verurteilen.” Meinong (1917), p. 137. 
analogous with the role of the productive process linked with classical higher order objects. The latter productive process was fine to ground the directedness of presentations and the intrinsic link between inferiora and superius. The former relationship, although taking place in a different way, shows the same virtue and is again grounded on presuppositional objects. The feature here taken into account is phenomenological. Indeed, Meinong argues that if $\mathrm{A}$ is the presuppositional object of a value-feeling $\mathrm{p}$ which presents the proper object $\mathrm{P}$, then the simultaneous givenness or the together being-given (Zusammengegebensein) of the objects $\mathrm{A}$ and $\mathrm{P}$ gives reason to presume that $\mathrm{A}$ has $\mathrm{P}^{17}$.

From this point of view, attributions of aesthetic properties seem to be true or justified attributions. As we can see, the togetherness of the access to presuppositional objects (represented) and to aesthetical features (emotionally presented) is the phenomenological criterion for such attributions. But dialectical considerations are also grounding this proposition. Such considerations, as stated above, aim to show that emotional presentation and its directedness are grounded on the multiples features involved by a deep consideration of the peculiarity of the intercourse between a subject and objects presenting aesthetical features. These objects, as they are to be conceived as higher order objects, involve the claim that a presuppositional objectum is necessary to understand our relationship with them. This is the consequence of the important internal dependence relation that cannot be avoided.

So beauty is a higher order object involving an objective-like entity, in order to be apprehended, because a duality is linked with presuppositional objects, and because emotions show a believing in the reality of the

"Dieser Ausgangspunkt scheint mir einfachst so formuliert werden zu sollen: Ist A der Voraussetzungsgegenstand für ein Wertgefühl p, das den Eigengegenstand $\mathrm{P}$ präsentiert, dann begründet das Zusammengegebensein der Gegenstände A und $\mathrm{P}$ eine Vermutung dafür, dass P dem A zukommt. [...] Hinzu kommt nun aber natürlich das überreiche Tatsachenmaterial, das in unserem Verhalten zu den ästhetischen Gegenständen beschlossen ist und wo jeder einzelne Fall des auf eine gegenständliche Voraussetzung gestellten Gefühles die Vermutungsevidenz für das Urteil involviert, daß der Eigengegenstand des Gefühles dem Voraussetzungsgegenstande als Eigenschaft zukomme." Meinong (1917), pp. $138,139$. 
"supervening" properties, as they occur. This furnishes a first clarification of the directedness's ontological value: emotions appear to be the proper link with aesthetic object, because as they are occurring, they show that some real properties are pressing them to occur. This real commitment is grounded on the idea that under some circumstances, we are compelled to directedness toward things that impose themselves. As aesthetic properties become the proper objects of aesthetic feelings, they show the pressure of some realistic connexions: those that are expressed in a Sosein objective-like, where such and such presuppositional objects appear to ground an aesthetic determination which is there as such, disregarding the real or imaginative existence of these presuppositional objects. So emotions behave like testifiers of some aesthetic connexions: the real pressure seems to come from the mysterious way by which aesthetic properties do belong to ordinary things.

The specific apparatus of the Theory of objects enables us to see that, as such, the theory combines and tries always to connect phenomenological facts with more dialectical moves. The impossibility to have beauty as an abstracted property is the impossibility to see it as an objectum. But the internal dependence doesn't give more easiness to the apprehension of beauty as a higher order object. Apprehension via objectives is also problematic, since beauty properties are not available as objecta. Apprehension of such things as higher order objects implies emotions, as these feelings occur in such a way that objective-like entities are involved, and especially Sosein-objective-likes entities. Emotions are directed toward such complex without giving the content of beauty objects. They are directed toward beauty because beauty obtains as property of presuppositional objects. This obtaining is what attracts emotions and grounds the directedness of such feelings. It justifies the attribution of beauty to the objects grounding the directedness in such a process. Thus, with such a meinongian view, we have a response-dependent theory - if we like to talk this way - that aims to reveal the obtaining of beauty as part of a complex. From this point of view, this is a realistic theory about beauty, insofar as beauty is conceived through the conditions that make it an ob- 
ject. We do not have a theory about what aesthetic properties are. We just know that sometimes, they truly are.

\section{Bruno Langlet}

Université de Provence (Aix-Marseille I) brunolanglet@orange.fr 


\section{Literature}

Barbero, Carola (2006), "Cry for a Shadow. Emotions and Object Theory", in V. Raspa [ed.] (2006), Meinongian Issues in Contemporary Italian Philosophy, Meinong Studies / Meinong Studien, vol. II, Frankfurt et al., Ontos Verlag, pp. 181-211.

Meinong, Alexius (1894), "Beiträge zur Theorie der psychischen Analyse", Zeitschrift für Psychologie und Physiologie der Sinnesorgane, 6, 1894, S. 340-385, 417-455; repr. in GA I, pp. 305-388.

Meinong, Alexius (1899), "Über Gegenstände höherer Ordnung und deren Verhältnis zur inneren Wahrnehmung", Zeitschrift für Psychologie und Physiologie der Sinnesorgane, 21, 1899, S. 182-272; repr. in GA II, pp. 377-471.

Meinong, Alexius (1900), “Abstrahieren und Vergleichen”, Zeitschrift für Psychologie und Physiologie der Sinnesorgane, 24, pp. 34-82; repr. in $G A$ II, pp. 443-492.

Meinong, Alexius (1910), Über Annahmen, 2. umgearbeitete Aufl., Leipzig, Barth; Nachdr. in GA IV, pp. 1-389, 517-535.

Meinong, Alexius (1917), Über emotionale Präsentation, in Sitzungsberichte der Akademie der Wissenschaften in Wien. Phil.-hist. Klasse, 183, Abh. 2, 1917; repr. in GA III, pp. 283-476.

Meinong, Alexius (1921), "A. Meinong [Selbstdarstellung]", in R. Schmidt [Hrsg.] (1921), Die deutsche Philosophie der Gegenwart in Selbstdarstellungen, Bd. 1, Leipzig, Meiner, S. 91-150; repr. in GA VII, pp. 1-62.

Meinong, Alexius (1968-1978), Alexius Meinong Gesamtausgabe, hrsg. von R. Haller und R. Kindinger gemeinsam mit R. M. Chisholm, Graz, Akademische Druck- und Verlagsanstalt [abbr.: GA].

Raspa, Venanzio (2006), "Fictional and Aesthetic Objects. Meinong's Point of View", in A. Bottani \& R. Davies [eds.] (2006), Modes of Existence. Papers in Ontology and Philosophical Logic, Frankfurt et al., Ontos Verlag, pp. 49-82. 
Schumann, Karl (2001), "Meinongian aesthetics", in L. Albertazzi, D. Jacquette \& R. Poli [eds.] (2001), The School of Alexius Meinong, Aldershot, Ashgate, pp. 517-540.

Smith, Barry (1996), "Pleasure and its modifications: Witasek, Meinong and the Aesthetics of the Grazer Schule", in L. Albertazzi [ed.] (1996), The Philosophy of Alexius Meinong, Axiomathes, VII, n. 1-2, pp. 203-232. 